\title{
SIFAT FISIK DAN ORGANOLEPTIK YOGURT DRINK SUSU KAMBING DENGAN PENAMBAHAN EKSTRAK KULIT MANGGIS (Garcinia mangostana L.)
}

\author{
Physical and Sensory Properties of Yogurt Drink from Goat's Milk with \\ Supplementation of Mangosteen Peel Extract (Garcinia mangostana L.) \\ Jeki Mediantari Wahyu Wibawanti ${ }^{1)}$, Rinawidiastuti ${ }^{1)}$ \\ 1) Department of Animal Science, University of Muhammadiyah Purworejo, Purworejo, Indonesia. 54111 \\ Email: jekiwibawanti@gmail.com
}

Diterima 25 September 2017; diterima pasca revisi 23 Maret 2018

Layak diterbitkan 28 Maret 2018

\begin{abstract}
The objective of this studies were to determine the physical properties of viscosity and organoleptic of yogurt drink with the suplementation of mangosteen peel extract. The experimental design used was Completely Randomized Design (CRD) of the factorial pattern. The first factor was the difference of mangosteen peel extract level $(0 \%, 3 \%$ and $6 \% \mathrm{v} / \mathrm{v})$, while the second factor was the storage time of yogurt $(0,1$, and 2 weeks) with 3 replications. The results showed that the supplementation of mangosteen peel extract on yogurt drink gave significant effect $(p<0.05)$ on viscosity, color and sensory analysis (viscosity and texture). Yogurt drink was recommendation with mangosteen peel extract 3\% (74.65cp), lightness $(L) 79.89$, redness $\left(a^{*}\right) 0.14$ yellowness $\left(b^{*}\right) 2.32$, sensory analysis of viscosity with score 2.84 (moderate viscosity), organoleptics of color 3.52 (white yelowness) and texture test with score 2.12 (moderate smooth). It can be concluded that the addition of mangosteen peel extract can improve the quality of physical, color, organoleptik yogurt drink. The use of mangosteen peel extract will increase the economic value and product diversification.
\end{abstract}

Keywords : Mangosteen peel extract; yogurt; goat milk; color; sensory analysis.

\begin{abstract}
ABSTRAK
Penelitian ini bertujuan untuk mengetahui kualitas fisik dan organoleptik yogurt drink dengan penambahan ekstrak kulit manggis. Rancangan percobaan yang digunakan adalah Rancangan Acak Lengkap (RAL) pola Faktorial. Faktor pertama perbedaan level ekstrak kulit manggis $10 \%$, 3\% dan $6 \% \mathrm{v} / \mathrm{v})$, sedangkan faktor kedua adalah masa simpan yogurt $(0,1$, dan 2 minggu) dengan 3 kali ulangan. Hasil penelitian menunjukkan bahwa penambahan ekstrak kulit manggis pada yogurt drink memberikan pengaruh nyata $(p<0,05)$ terhadap sifat fisik viskositas, warna, uji organoletik, kekentalan dan tekstur. Yogurt drink dengan perlakuan penambahan ekstrak kulit manggis 3\% nilai viskositas sebesar 74,65 cp, lightness (L) 79,89, redness ( $\left.a^{*}\right)$ 0,14 yellowness ( $\left.b^{*}\right)$ 2,32, uji organoleptik kekentalan dengan skor 2,84 (agak kental), uji organoleptik warna 3,52 (putih kecoklatam) dan uji organoleptik tekstur dengan skor 2,12 (agak halus). Berdasarkan hasil penelitian dapat disimpulkan bahwa penambahan ekstrak kulit manggis dapat meningkatkan kualitas fisik, warna, organoleptik yogurt drink. Penggunaan ekstrak kulit manggis akan meningkatkan nilai ekonomis dan diversifikasi produk.
\end{abstract}

Kata Kunci : Ekstrak kulit manggis; yogurt; susu kambing; warna; organoleptik. 


\section{PENDAHULUAN}

Susu kambing mempunyai komposisi nutrisi dan karakteristik yang unik bila dibandingkan dengan susu sapi. Susu kambing kaya akan lemak, protein, mineral, vitamin A maupun vitamin B (riboflavin) (Shu et al., 2013). Susu kambing memiliki globula atau butiran lemak dengan ukuran kecil, hal ini akan mempermudah proses pencernaan dalam tubuh (Yangilar, 2013). Namun, susu kambing memiliki aroma prengus yang disebabkan oleh lemak susu yang mengandung asam lemak kaprat, kaprilat dan kaproat (Boycheva et al,. 2011), sehingga untuk mengurangi aroma prengus itu perlu dilakukan pengolahan. Proses pengolahan susu kambing dapat dilakukan dengan fermentasi. Proses fermentasi bertujuan untuk meningkatkan nutrisi, dan citarasa sehingga akan memberikan tambahan nilai suatu produk (Kustyawati dkk, 2012). Salah satu produk fermentasi adalah dibuat menjadi yogurt drink.

Yogurt drink merupakan produk fermentasi oleh bakteri asam laktat seperti Streptococcus thermophilus dan Lactobacillus bulgaricus (Cossu et al., 2009). Peningkatan kualitas yogurt drink dapat dilakukan dengan memberikan penambahan ekstrak kulit manggis (Wibawanti et al., 2018). Kulit manggis mengandung senyawa xanton dan turunannya yang merupakan senyawa yang dapat berperan dalam menjaga kesehatan (Jung et al., 2006). Salah satu peran xanton sebagai senyawa antioksidan (Chaverri et al., 2008). Senyawa antioksidan berperan dalam menangkal aktivitas radikal bebas (Arazo et al., 2011). Yogurt drink susu kambing dengan penambahan ekstrak kulit manggis berpotensi menjadi minuman fungsional untuk kesehatan. Selama ini masyarakat hanya mengkonsumsi buah manggisnya, padahal disisi lain, kulit

\footnotetext{
*Corresponding author:

Jeki Mediantari Wahyu Wibawanti

Email : jekiwibawanti@gmail.com

Department of Animal Science, University of

Muhammadiyah Purworejo, Purworejo, Indonesia.

54111
}

manggis yang sering kali hanya sebagai limbah memiliki khasiat untuk kesehatan. Selain itu penambahan ekstrak kulit manggis dimungkinkan juga akan mempengaruhi sifat fisik yogurt. Kulit manggis dapat diekstrak sebagai pewarna alami (Saraswati dan Astutik, 2011). Salah satu upaya pemanfaatan produk berbasis kulit manggis dengan ekstraksi antosianin kulit manggis (Farida dan Nisa, 2015). Dimana ekstrak kulit manggis ini nantinya dapat dijadikan sebagai pewarna alami yang khas pada yogurt. Oleh karena itu, penelitian penambahan ekstrak kulit manggis pada yogurt drink ini bertujuan untuk mengetahui karakter fisik, warna dan organoleptik yogurt drink dengan penambahan ektrak kulit manggis.

\section{MATERI DAN METODE}

Penelitian ini dilaksanakan di Laboratorium Terpadu Universitas Muhammadiyah Purworejo dan Laboratorium Uji Teknologi Pangan dan Hasil Pertanian, Universitas Gadjah Mada. Materi Penelitian yang digunakan adalah susu kambing dari Ds. Tlogoguwo dan kulit manggis dari Ds Somongari Kec.Kaligesing Kab. Purworejo. Susu kambing dengan kualitas fisik yang masih segar, warna putih kekuningan dan memiliki aroma khas kambing. Kulit manggis yang digunakan adalah kulit bagian dalam yang berwarna coklat. Rancangan penelitian yang digunakan dalam penelitian yogurt drink ekstrak kulit manggis ini adalah Rancangan Acak Lengkap (RAL) pola faktorial. Faktor pertama perbedaan level ekstrak kulit manggis $(0 \%, 3 \%$ dan $6 \% \mathrm{v} / \mathrm{v})$, dan faktor kedua yaitu masa simpan yogurt $(0,1$, dan 2 minggu $)$ dengan 3 kali ulangan.

\footnotetext{
How to cite:

Wibawanti, J.M., \& Rinawidiastuti. (2018). Sifat Fisik dan Organoleptik Yogurt Drink Susu Kambing dengan Penambahan Ekstrak Kulit Manggis (Garcinia mangostana L.). Jurnal Ilmu dan Teknologi Hasil Ternak, 13 (1), 27-37
} 


\section{Prosedur Pembiakan Starter Yogurt Drink}

Pembuatan starter yogurt drink dilakukan dengan pembuatan mother culture starter (starter induk) dan bulk starter (starter kerja). Starter induk ditumbuhkan dalam MRS broth, sedangkan starter kerja dalam susu. Cara pembuatan starter induk dengan menumbuhkan kultur murni Streptococcus thermophilus (FNCC-0040) dan Lactobacillus bulgaricus (FNCC-0041) dalam 5,2 gram MRS broth yang diencerkan dalam aqudes sebanyak $100 \mathrm{~mL}$ MRS broth disterilkan pada suhu $121^{\circ} \mathrm{C}$ selama 10 menit. Dilanjutkan dengan proses inkubasi selama 24 jam pada suhu ruang. Starter yang telah tumbuh, disimpan pada kulkas. Pembuatan starter kerja (bulk starter) dimulai dengan menyiapakan susu UHT. Susu UHT dilakukan pasteurisasi, kemudian suhu diturunkan sampai mencapai suhu $43^{\circ} \mathrm{C}$, yang dilanjutkan diinokulasi dengan starter sebanyak $5 \%$.

\section{Prosedur Pembuatan Ekstrak Kulit Manggis}

Pembuatan ekstrak kulit manggis dilakukan dengan cara memilih kulit manggis bagian dalam yang sudah kering. Kemudian dilakukan penimbangan kulit manggis sebanyak 200 g. Tahap selanjutnya dilakukan penambahan aquades sebanyak $1 \mathrm{~L}$ dan dihomogenkan. Selanjutnya dilakukan penyaringan dengan kertas saring. Hasil dari saringan dimasukkan dalam sentrifuge dengan kecepatan 6000 rpm selama 10 menit dan diperoleh ekstrak kulit manggis (modifikasi dari Vinderola et al., 2002).

\section{Prosedur Pembuatan Yogurt Drink Ekstrak Kuli Manggis}

Langkah awal pembuatan yogurt drink yaitu pasteurisasi susu kambing yang ditambahkan susu skim pada suhu $\pm 72^{\circ} \mathrm{C}$ selama 15 menit. Kemudian suhunya diturunkan sampai mencapai $\pm 42^{\circ} \mathrm{C}$. Setelah itu dinokulasikan dengan starter kerja bakteri asam laktat sebanyak 5\%. Dilanjutkan dengan proses inkubasi (suhu $37^{\circ} \mathrm{C}$ selama 16 jam). Langkah selanjutnya ekstrak kulit manggis ditambahkan sesuai perlakuan. Yogurt drink yang sudah jadi kemudian disimpan di dalam kulkas untuk dilakukan pengujian setiap minggunya selama 2 minggu.

\section{Pengujian Viskositas}

Pengujian viskositas yogurt drink bertujuan untuk mengetahui tingkat kekentalan sampel. Pengujian viskositas dengan menggunakan alat Viskometer. Viskometer dinyalakan kemudian dipasang spindle. Sampel sebanyak $100 \mathrm{ml}$ dicelupkan sampai menyentuh spindle, kemudian angka yang muncul dicatat.

\section{Pengujian Warna}

Pengujian warna yogurt drink dilakukan dengan menggunakan alat Choromameter Konica Minolta CR-400. Sampel yogurt dimasukkan pada alat, kemudian color reader ditempelkan pada permukaan sampel. Tombol pembacaan diatur pada $\mathrm{L}^{*}$ (lightness), $\mathrm{a}^{*}$ (redness) dan $\mathrm{b}^{*}$ (yellowness) dan tombol target ditekan. Hasil dari pembacaan alat dicatat.

\section{Pengujian Organoleptik Kekentalan, Tekstur dan Warna}

Uji organoleptik kekentalan dan tekstur dilakukan dengan tujuan untuk mengetahui respon panelis terhadap tingkat kekentalan dan tekstur yogurt drink susu kambing. Uji ini bedasarkan pada uji mutu hedonik. Pengujian dilakukan dengan menggunakan 25 panelis agak terlatih dengan kriteria umur 20-25 tahun. Panelis memberikan penilaian terhadap sampel dengan mengisi form organoleptik nilai kisaran skor 1-4. Skor uji organoleptik kekentalan yaitu tidak kental $=1$, agak kental $=2, \operatorname{kental}=3$, sangat kental $=4$. Skor uji organoleptik tekstur sebagai berikut tidak halus $=1$, agak halus $=2$, halus $=3$ dan sangat halus $=4$, sedangkan skor uji organoleptik warna meliputi $1=$ putih, $2=$ putih kekuningan, $3=$ putih kecoklatan dan $4=$ sangat coklat. 


\section{Analisis Data}

Data yang diperoleh dari pengujian sifat fisik viskositas yogurt drink dianalisis dengan Analisis of Variance (ANOVA), apabila pengujian yogurt drink signifikan maka, data dilanjutkan uji Duncan dengan taraf signifikansi 5\%. Pengujian organoleptik untuk kekentalan dan tekstur dengan uji panelis dilanjutkan secara statistis dengan Friedman Test.

\section{HASIL DAN PEMBAHASAN}

\section{Nilai Viskositas}

Perubahan kekentalan yogurt drink selama proses fermentasi merupakan aktivitas bakteri asam laktat yang menguraikan padatan. Data pengujian nilai viskositas yogurt drink dengan penambahan ekstrak kulit manggis dengan lama penyimpanan berbeda dapat dilihat pada Tabel 1. Hasil penelitian menunjukkan bahwa yogurt drink dengan penambahan konsentrasi ekstrak kulit manggis dalam lama penyimpanan berbeda menunjukkan hasil yang berpengaruh nyata $(\mathrm{p}<0,05)$ terhadap nilai viskositas. Interaksi antara penambahan ekstrak kulit manggis dengan waktu penyimpanan berbeda juga menunjukkan hasil signifikan $(\mathrm{p}<0,05)$ terhadap nilai viskositas. Semakin lama penyimpanan menyebabkan viskositas semakin menurun. Perbedaan nilai viskositas ini dimungkinkan oleh penambahan ekstrak kulit manggis dalam yogurt drink. Wibawanti et al. (2018) menyampaikan bahwa penambahan ekstrak kulit manggis dapat menyebabkan perbedaan karakteristik fisik yogurt.

Selain itu perubahan nilai viskositas juga dimungkinkan adanya aktivitas bakteri dalam hal ini bakteri asam laktat selama proses fermentasi yang dapat mempengaruhi kekentalan susu. Laktosa akan dirombak menjadi asam laktat oleh bakteri asam laktat sehingga akan menghasilkan enzim laktase yang dapat mempengaruhi viskositas. Hasil penelitian juga menunjukkan semakin lama masa simpan dalam refrigerator nilai viskositasya semakin menurun. Hal ini menunjukkan bahwa lama simpan yogurt drink mempengaruhi viabilitas bakteri asam laktat. Wahyudi dan Samsundari (2008) menyatakan bahwa adanya peningkatan total asam yang dipengaruhi oleh bakeri asam laktat dalam membentuk asam laktat, sehingga terbentuk gel oleh koagulasi kasein. Pembentukan gel mengakibatkan perubahan tekstur dan kekentalan (viskositas). Jaya dkk (2011) menjelaskan bahwa viskositas minuman probiotik yogurt juga dipengaruhi oleh isolat bakteri yang digunakan.

Tabel 1. Viskositas (cP) Yogurt Drink dengan Penambahan Ekstrak Kulit Manggis Lama Penyimpanan (minggu)

\begin{tabular}{ccccc}
\hline Konsentrasi EKM & 0 & 1 & 2 & Rerata \\
\hline$\%$ & $44.5 \pm 0.14$ & $14 \pm 0.07$ & $19.8 \pm 0.07$ & $26.11^{\mathrm{a}}$ \\
$3 \%$ & $38.8 \pm 2.89$ & $18 \pm 0.35$ & $68 \pm 0.07$ & $74.65^{\mathrm{c}}$ \\
$6 \%$ & $69.75 \pm 0.35$ & $13.3 \pm 0.07$ & $29.3 \pm 0.14$ & $37.47^{\mathrm{b}}$ \\
Rerata & $50.59^{\mathrm{a}}$ & $48.59^{\mathrm{b}}$ & $39.05^{\mathrm{c}}$ \\
\hline
\end{tabular}

Keterangan: ${ }^{a, b, c}$ Superskrip berbeda pada kolom yang sama menunjukkan perbedaan yang nyata $(\mathrm{p}<0,05)$

\section{Uji Warna Lightness (L) Warna Yogurt Drink}

Nilai lightness (L) dinyatakan dalam kisaran 0-100, dimana 0 menunjukkan warna hitam, sedangkan nilai 100 menunjukkan warna putih. Hasil analisis ragam pengukuran tingkat kecerahan (L) bahwa yogurt drink yogurt drink susu kambing yang diberikan ekstrak kulit manggis menunjukkan adanya pengaruh nyata $(\mathrm{p}<0,05)$ terhadap warna. Waktu penyimpanan yang berbeda tidak memberikan pengaruh nyata $(p>0,05)$ pada warna. Interaksi antara 
penambahan ekstrak kulit manggis dengan waktu penyimpanan berbeda juga tidak memberikan pengaruh nyata $(p>0,05)$ terhadap warna. Berdasarkan data dalam Tabel 2. menunjukkan bahwa rerata nilai lightness (L) penelitian berkisar 76,05 sampai 80,05 dengan warna lightness (L) tertinggi sebesar 80,05 diperoleh yogurt drink tanpa penambahan ekstrak kulit manggis, sedangkan nilai warna lightness (L) terendah didapat pada yogurt drink dengan penambahan ekstrak kulit manggis sesesar 6\%. Hasil penelitian menunjukkan bahwa penambahan ekstrak kulit manggis menurunkan tingkat lightness yogurt drink susu kambing.

Tabel 2. Uji Lightness (L) Warna Yogurt Drink dengan Penambahan Ekstrak Kulit Manggis

\begin{tabular}{ccccc}
\hline \multicolumn{2}{c}{ Lama Penyimpanan (minggu) } & & \\
\hline Konsentrasi EKM & 0 & 1 & 2 & Rerata \\
\hline $0 \%$ & $82.09 \pm 2.24$ & $77.06 \pm 4.37$ & $80.99 \pm 0.86$ & $80.05^{\mathrm{a}}$ \\
$3 \%$ & $78.06 \pm 3.63$ & $82.37 \pm 2.67$ & $79.26 \pm 1.37$ & $79.89^{\mathrm{a}}$ \\
$6 \%$ & $78.21 \pm 0.87$ & $75.85 \pm 3.16$ & $74.95 \pm 6.75$ & $76.25^{\mathrm{b}}$ \\
Rerata & 79.46 & 78.34 & 78.39 \\
\hline
\end{tabular}

Keterangan: ${ }^{a, b}$ Superskrip berbeda pada kolom yang sama menunjukkan perbedaan yang nyata $(\mathrm{p}<0,05)$

Perbedaan warna pada yogurt drink ini dimungkinkan adanya level penambahan ekstrak kulit manggis. Ekstrak kulit manggis memberikan warna yang lebih gelap. Saraswati dan Astutik (2011) menyatakan bahwa kulit manggis dapat memberikan warna alami pada pangan. Farida dan Nisa (2015) menjelaskan bahwa pemanfaatan kulit manggis untuk pewarna dengan cara ekstraksi antosianin. Gupita (2012) menambahkan pigmen antosianin akan membentu warna merah keunguan dan pada $\mathrm{pH}$ asam akan membuat mejadi semakin merah.

\section{Uji Warna Redness (a*) Yogurt Drink}

Rerata nilai uji warna a* (redness) yogurt drink dengan penambahan ekstrak kulit manggis dalam lama penyimpanan berbeda menunjukkan hasil yang berpengaruh nyata $(p<0,05)$. Interaksi antara penamabahan ekstrak kulit manggis dalam waktu penyimpanan berbeda menunjukkan hasil tidak signifikan ( $p>0,05)$. Data pengujian warna kemerahan $a^{*}$ yogurt drink dengan penambahan ekstrak kulit manggis dalam lama penyimpanan berbeda dapat dilihat pada Gambar 1. Berdasarkan data dalam Gambar 1. Rata-rata nilai penelitian a* (redness) berkisar antara 0,20 hingga 0,54 dengan warna $\mathrm{a}^{*}$ (redness) tertinggi pada penambahan ekstrak kulit manggis $6 \%$ dengan skor 0,54, sedangkan warna $\mathrm{a}^{*}$ (redness) terendah dengan skor 0,20 pada yogurt drink tanpa penambahan ekstak kulit manggis. 


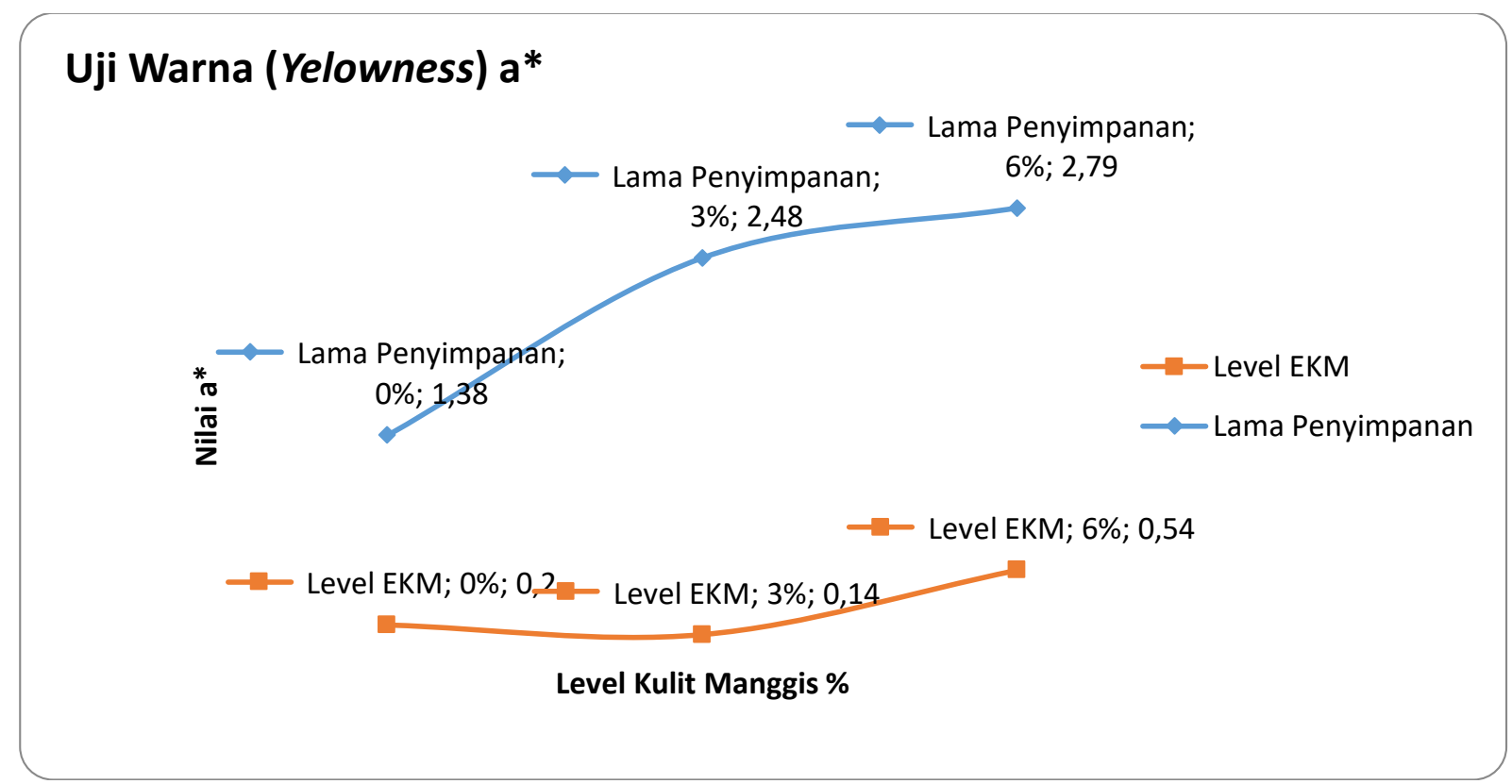

Gambar 1. Uji Warna Redness (a*) Yogurt Drink

Hal ini dimungkinkan bahwa penambahan ekstrak kulit manggis memberikan peningkatan terhadap nilai kemerahan pada yogurt drink. Perbedaan warna pada yogurt drink ini dimungkinkan adanya penambahan ekstrak kulit manggis sebagai pewarna alami. Saraswati dan Astutik (2011) menyatakan bahwa salah satu bahan pewarna alami yaitu dari kulit manggis. Farida dan Nisa (2015) menjelaskan kulit manggis yang banyak mengandung antioksidan seperti senyawa pigmen antosianin. Gupita (2012) memaparkan bahwa selain pigmen antosianin pada kulit manggis juga terdapat pigmen xanton yang berpengaruh terhadap warna.

\section{Uji Warna Yellowness (b*) Yogurt Drink}

Hasil analisis ragam menunjukkan bahwa penambahan ekstrak kulit manggis dengan level yang berbeda memberikan pengaruh nyata $(p<0,05)$ terhadap uji warna kekuningan $\left(b^{*}\right)$ yogurt drink susu kambing. Perbedaan lama waktu penyimpanan dan interaksi antara penambahan ekstrak kulit manggis dalam lama penyimpanan berbeda menunjukkan hasil yang tidak berpengaruh nyata $(\mathrm{p}<0,05)$. Berdasarkan Gambar 2. rerata uji warna kekuningan berkisar antara 1,11 hingga 3,22 dengan warna $b^{*}$ (yellowness) tertinggi sebesar 3,22. 


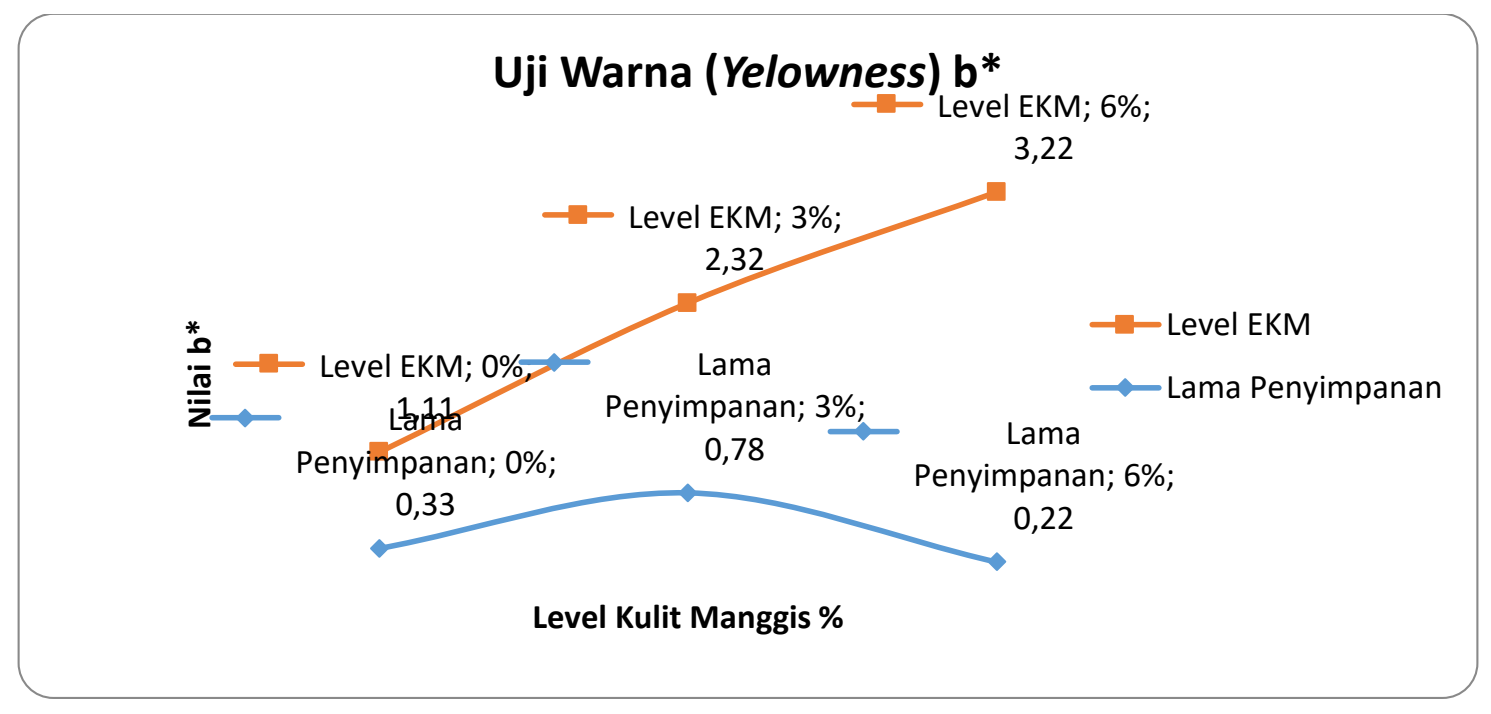

Gambar 2. Uji Warna Yellowness ( $\mathrm{b} *$ ) Yogurt Drink

Hal ini menunjukkan bahwa penambahan ekstrak kulit manggis yang semakin tinggi memberikan peningkatan terhadap nilai kekuningan pada yogurt drink. Penggunaan ekstrak kulit manggis dapat memberikan pewarna dalam yogurt drink. Wibawanti et al. (2018) menyatakan bahwa yogurt drink yang diberikan ekstrak kulit manggis memberikan warna yang lebih yellowness dibandingkan dengan yogurt tanpa penambahan ekstrak kulit manggis. Saraswati dan Astutik (2011) menjelaskan bahwa kulit manggis memiliki pigmen antosianin yang dapat berfungsi sebagai pewarna. Farida dan Nisa (2015) menambahkan kandungan pigmen antosianin yang ada pada kulit manggis sebesar 593 ppm. Bulele dkk (2017) menambahkan produk pangan dengan pewarna alami kulit manggis akan lebih memiliki warna yang menarik.

\section{Uji Organoleptik Kekentalan}

Data hasil rerata penelitian penambahan ekstrak kulit manggis pada yogurt drink menunjukkan adanya pengaruh nyata $(\mathrm{p}<0,05)$ terhadap uji organoleptik kekentalan. Uji organoleptik kekentalan dapat dilihat pada Gambar 3. Panelis menganggap bahwa yogurt drink kontrol menunjukkan hasil agak kental dengan skor rerata 2,48. Penambahan ekstrak kulit manggis 3\% menunjukkan hasil yang sama yakni agak kental dengan skor rerata 2,84, sedangkan yogurt drink dengan penambahan ekstrak kulit manggis 6\% menunjukkan hasil kental dengan rerata skor 3,44 .

Hal ini diduga berhubungan dan penambahan ekstrak kulit manggis, konsentrasi penambahan ekstrak kulit manggis yang semakin tinggi menyebabkan kekentalan yogurt drink semakin tinggi. Hal tersebut juga terjadi karena perbedaan persepsi panelis dalam memberikan penilaian yogurt drink dengan penambahan ekstrak kulit manggis. Selain itu nilai viskositas dipengaruhi oleh total bakteri asam laktat, $\mathrm{pH}$ maupun keasaman.

Semakin tinggi jumlah bakteri asam laktatnya, maka biasanya pHnya semakin rendah diikuti dengan kenaikan nilai keasaman. Damunupola (2014) menyatakan bahwa proses fermentasi menyebabkan penguraian padatan oleh bakteri asam laktat. Wibawanti et al. (2018) menambahkan penurunan nilai $\mathrm{pH}$ dipengaruhi oleh pertumbuhan bakteri asam laktat. Widagdha dan Nisa (2015) mengemukakan bahwa semakin lama waktu fermentasinya menyebabkan nilai viskositas semakin tinggi yang disebabkan oleh jumlah asam laktat yang dihasilkan dari bakteri asam laktat jumlahnya bertambah. 


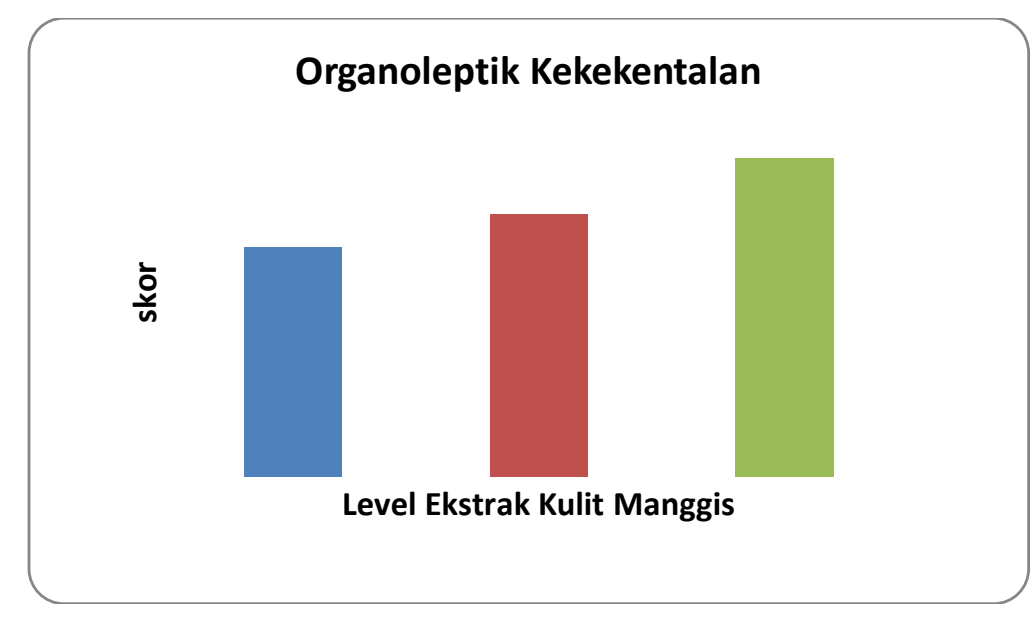

Gambar 3. Grafik Organoleptik Kekentalan Yogurt Drink

\section{Uji Organoleptik Tekstur}

Hasil penilaian uji organoleptik testur menunjukkan bahwa penambahan ekstrak kulit manggis menunjukkan pengaruh nyata $(p<0,05)$ terhadap tekstur. Uji organoleptik tekstur ditampilkan pada Gambar 4. Hasil penelitian yogurt drink kontrol menunjukkan rerata skor 2,24 dengan kriteria agak halus. Penambahan ekstrak kulit manggis 3\% menunjukkan hasil tekstur yang agak halus dengan rerata skor 2,12, sedangkan yogurt drink dengan penambahan ekstrak kulit manggis $6 \%$ menunjukkan tekstur tidak halus dengan rerata skor 1,64. Perbedaan tekstur dapat dimungkinkan penguraian padatan yang dilakukan bakteri asam laktat selama proses fermentasi. Hal ini sesuai dengan pendapat Sumarmono et al. (2015) yang menyatakan bahwa bakteri asam laktat seperti Lactobacillus bulgaricus dan Streptococcus thermophilus berkontribusi terhadap komposisi, tekstur dan sensoris. Peningkatan konsentrasi penambahan ekstrak kulit manggis menyebabkan perbedaan tekstur pada yogurt drink. Susilorini dan Sawitri (2006) menyatakan bahwa bakteri menghasilkan enzim laktase yang mempengaruhi kekentalan susu sehingga berpengaruh terhadap tekstur. Winarno dan Fernandes (2007) menjelaskan jumlah bagian total solid juga akan berpengaruh pada kekentalan maupun tekstur yogurt drink.

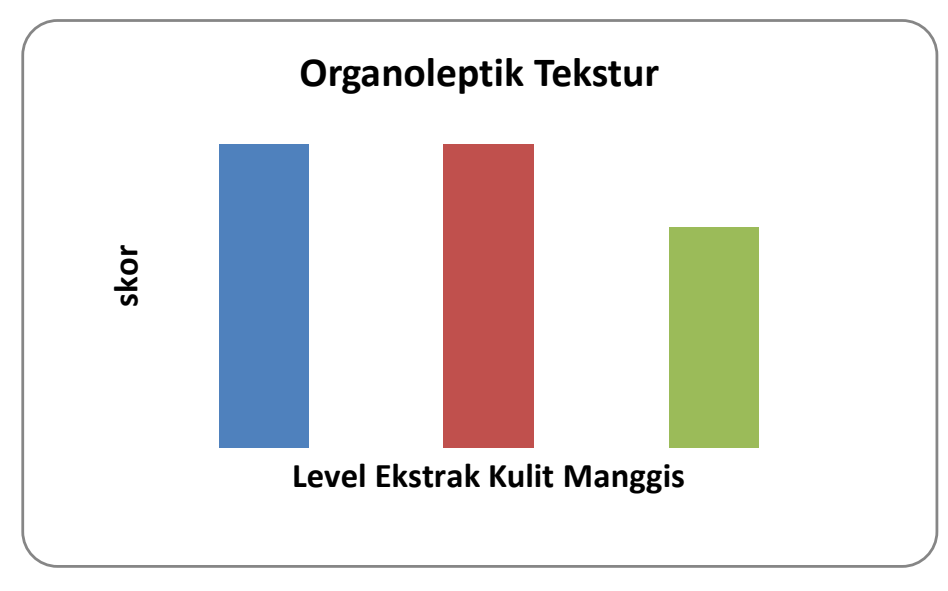

Gambar 4. Grafik Organoleptik Tekstur Yogurt Drink 


\section{Uji Organoleptik Warna}

Hasil uji organoleptik warna yogurt drink susu kambing dengan penambahan ekstrak kulit manggis secara statistik memberikan pengaruh nyata $(\mathrm{p}<0,05)$. Hasil ini dapat dilihat pada Gambar 5. Hal tersebut menunjukkan bahwa penambahan ekstrak kulit manggis memberikan kesan berbeda dari panelis. Yogurt drink kontrol menunjukkan warna hasil putih kecoklatan dengan skor 3,37. Penambahan ekstrak kulit manggis 3\% menghasilkan skor 3,52 dengan warna putih kecoklatan, sedangkan penambahan ekstrak kulit manggis 6\% menunjukkan warna putih kecoklatan dengan skor 3 . Perbedaan skor panelis ini dimungkinkan oleh level penambahan ekstrak kulit manggis yang berbeda.

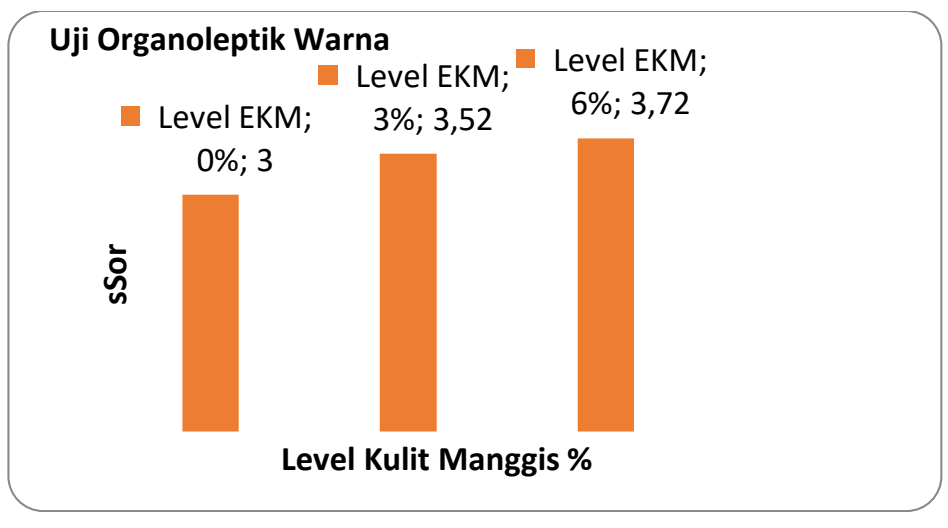

Gambar 5. Grafik Organoleptik Warna Yogurt Drink

Penambahan ekstrak kulit manggis dimungkinkan dapat berperan sebagai bahan pewarna alami yang dapat meningkatkan daya tarik. Bulele dkk (2017) menyatakan bahwa pewarna alami dari kulit manggis dapat digunakan sebagai bahan alami pewarna pangan yang dapat meningkatkan daya tarik konsumen. Farida dan Nisa (2015) menjelaskan pewarna dari kulit manggis ini berasal dari pigmen antosianin

\section{KESIMPULAN}

Berdasarkan hasil penelitian dapat disimpulkan bahwa penambahan ekstrak kulit manggis dapat meningkatkan kualitas fisik, warna, organoleptik yogurt drink. Penggunaan ekstrak kulit manggis akan meningkatkan nilai ekonomis dan diversifikasi produk.

\section{UCAPAN TERIMA KASIH}

Peneliti menyampaikan terima kasih kepada KEMENRISTEKDIKTI atas dukungan dana penelitian ini skim Penelitian Dosen Pemula (PDP) 2017 serta Lembaga Penelitian dan Pengabdian Masyarakat (LPPM) Universitas Muhammadiyah Purworejo atas supportnya.

\section{DAFTAR PUSTAKA}

Arazo, M., Bello, A., Rastrelli, L., Montelier, M., Delgado, L., \& Panfet, C. (2011). Antioxidant properties of pulp \& peel of yellow mangosteenfruits. Emirates Journal of Food and Agriculture, 23(6), 517-524.

Boycheva, S., Dimitrov, T., Naydenova, N., \& Mihaylova, G. (2011). Quality characteristics of yogurt from goat's milk, supplemented with fruit juice. Czech $J$. Food Sci, 29(1), 24-30. Retrieved from http://www.agriculturejournals.cz/publicFi les/35010.pdf

Bulele, A., Pongoh, J., \& Reo, A. (2017). 
Tingkat kesukaan konsumen terhadap ikan cakalang (Katsowonus pelamis L.) asap yang direndam dalam ekstraksi kulit manggis. Jurnal Media Teknologi Hasil Perikanan, 5(1), 113-117. Retrieved from https://ejournal.unsrat.ac.id/index.php/jmt hp/article/view/14910

Chaverri, J. P., Rodriguez, N. C., Ibarra, M. O., \& Rojas, P. (2008). Medicinal properties of mangosteen (Garcinia mangostana). Food \& Chemical Toxicology, 46(10), 3227-3239.

https://doi.org/10.1016/J.FCT.2008.07.024

Cossu, M., Pisu, R., Juliano, C. C., \& Alamanni, M. C. P. (2009). Effects of enrichment with polyphenolic extracts from Sardinian plants on physicochemical, antioxidant and microbiological properties of yogurt. Italian Journal of Food Science, 21(4), 447-459.

Damunupola, D. A. P. R., Weerathilake, W. A. D. V, \& Sumanasekara, G. S. (2014). Evaluation of quality characteristics of goat milk yogurt incorporated with beetroot juice. International Journal of Scientific \& Research Publications, 4(10), $2-5$.

Gupita, C. N., (2012). Pengaruh berbagai pH sari buah dan suhu pasteurisasi terhadap aktivitas antioksidan \& tingkat penerimaan sari kulit buah manggis. Universitas Diponegoro, Semarang.

Jaya, F., Kusumahadi, D., \& Amertaningtyas, D. D. (2011). Pembuatan minuman probiotik (yogurt) dari proporsi susu sapi dan kedelai dengan isolat lactobacillus casei \& lactobacillus plantarum the making of probiotic drink (yogurt) from cow s milk \& soybean proportion using lactobacillus casei \& lactobacil. Jurnal Ilmu \& Teknologi Hasil Ternak, 6(1), 13$17 . \quad$ Retrieved from http://jitek.ub.ac.id/index.php/jitek/article/
viewFile/166/157

Jung, H.-A., Su, B.-N., Keller, W. J., Mehta, R. G., \& Kinghorn, A. D. (2006). Antioxidant xanthones from the pericarp of garcinia mangostana (mangosteen). Journal of Agricultural \& Food Chemistry, 54(6), 2077-2082. https://doi.org/10.1021/jf052649z

Kustyawati, M. E., Tobing, S. D., \& Trimaryanto. (2012). Profil asam lemak \& asam amino susu kambing segar \& terfermentasi fatty acid and amino acid profile of fresh \& fermented goat milk. Jurnal Teknologi Dan Industri Pangan, 23(1), 47-52. Retrieved from http://journal.ipb.ac.id/index.php/jtip/articl e/view/5293

Saraswati, D. N \& Astutik, S.E. (2011). Ekstraksi zat warna alami dari kulit manggis serta uji stabilitasnya. Fakultas Teknik, Universitas Diponegoro, Semarang.

Shu, G., Li, C., Chen, H., \& Wang, C. (2014). Effect of inoculum \& temperature on the fermentation of goat yogurt. Advance Journal of Food Science and Technology, $6(1), 68-71$.

https://doi.org/10.19026/ajfst.6.3032

Sumarmono, J., Sulistyowati, M., \& Soenarto. (2015). Fatty acids profiles of fresh milk, yogurt \& concentrated yogurt from peranakan etawah goat milk. Procedia Food Science, 3, 216-222. https://doi.org/10.1016/J.PROFOO.2015.01.024

Vinderola, C. ., Costa, G. ., Regenhardt, S., \& Reinheimer, J. . (2002). Influence of compounds associated with fermented dairy products on the growth of lactic acid starter and probiotic bacteria. International Dairy Journal, 12(7), 579589.https://doi.org/10.1016/S0958-6946(02)00046-8 
Wahyudi, A dan S. Samsundari. (2008). Bugar dengan Susu Fermentasi. Malang, Indonesia, Universitas Muhammadiyah Malang Press.

Wibawanti, J. M. W., Rinawidiastuti, Arifin, H. D., \& Zulfanita. (2018). Improving characteristics of goat milk yogurt drink fortified by mangosteen rind ( Garcinia mangostana Lin .) extract. IOP Conference Series: Earth and Environmental Science, 102, 12008. https://doi.org/10.1088/1755-1315/102/1/012008
Wigagha, S., \& Nisa, F. C. (2015). Pengaruh penambahan sari anggur (vitis vinifera 1.) \& lama fermentasi terhadap karakteristik fisiko kimia yogurt. Jurnal Pangan dan Agroindustri. Jurnal Pangan \& Agroindustri, 3(1), 248-258.

Winarno, F.G \& Fernandez, L.E. (2007). Susu $\&$ produk fermentasinya.Bogor, Indonesia M Brio Press.

Yangliar, F. (2013). As a potentially functional food: goats' milk and products. Journal of Food and Nutrition Research, 1(4), 6881. https://doi.org/10.12691/jfnr-1-4-6 